Ph. D. in law, Assistant Professor of Criminal Procedure and Organization of Pre-Trial Investigation Department of the Faculty № 1,

Kharkiv National University of Internal Affairs; e-mail: r_chicha@ukr.net; ORCID ID: 0000-0003-3267-2840

Yevdokimenko S. $V$.

Doctor of Law, Assistant Professor of the Department of Finances and Accounting, Kharkiv Economics and Law University; e-mail: evdokimenko_s_v@ukr.net; ORCID ID: 0000-0003-2924-6621

\title{
ADAPTATION OF BUDGETARY LEGISLATION OF UKRAINE TO THE REQUIREMENTS OF THE EUROPEAN UNION AND THE IMPACT OF ECONOMIC RISKS ON THE STATE BUDGET INDICATORS
}

Abstract. Ukraine is on the way budget relationships reform realization, one of which tasks is adaptation of current legislation to EU legislation in order to create European conditions of development in country and in budget system particularly.

Budget control is the type of state finance control, integrated and telic system of economic and legal measures of authorized control subjects, aimed on providing of eligibility and effectiveness of budget process parties while drafting, reviewing, adoption of budgets, fulfillment, amending, considering reports on budgets' fulfillment, which compose the budget system of Ukraine. From that point of view the title of Chapter 17 of Budget Code of Ukraine (hereinafter $\mathrm{BCU}$ ) "Control on maintenance of budget legislation" means not the essence of state finance control but its aim. The powers of controlling subjects which are established by this chapter have mostly duplicative character while current Chapter 5 of BCU determines types of budget legislation violations and means of influence for such violations still contains inaccuracies and gaps in expression of legal norms concerning budget control.

Lack of budget control principles implementation on the regulatory level causes commitment of budget violation. On Accounting Chamber reports while fulfilling the controlling measures concerning the effectiveness of budget funds usage for ensuring activities and performing powers of public authorities more than 23 million UAH have been identified as used with violation of the requirements of the current legislation, and almost 313 million UAH were used inefficiently According to the calculations, the state budget short received income of almost 0.6 million UAH and also 10.3 million UAH were transferred to budgets exceeding the established deadlines/ Thus, the system of budgetary control requires improvement by defining a modern concept of its organization and implementing appropriate amendments to the current legislation. With this aim the authors have studied international experience, which shows the necessity of integrating new contemporary concept of budgetary control, which should be oriented to preliminary and current budgetary control.

Keywords: budget law, adaptation, budget control, amenability, controlling subjects, violations, public funds, financial control.

JEL Classification: H61, K3

Formulas: 0; fig.: 0; tabl.: 0; bibl.: 25.

Міщенко Л. В. к.юр.н., дочент кафедри правового забезпечення господарської діяльності факультету № 6 Харківського начіонального університету внутрішніх справ; e-mail: forsazh088@gmail.com; ORCID ID: 0000-0003-4906-8287 
Чича Р. П.

к.юр.н., доцент кафедри кримінального процесу та організації досудового слідства факультету № 1 Харківського начіонального університету внутрішніх справ; e-mail: r_chicha@ukr.net; ORCID ID: 0000-0003-3267-2840

Свдокіменко С. В.

д-р юр. н., дочент кафедри фінансів, обліку і аудиту

Харківського економіко-правового університету; e-mail: evdokimenko_s_v@ukr.net; ORCID ID: 0000-0003-2924-6621

\section{АДАПТАЦІЯ БЮДЖЕТНОГО ЗАКОНОДАВСТВА УКРАЇНИ ДО ВИМОГ ЄВРОПЕЙСЬКОГО СОЮЗУ ТА ВПЛИВ \\ ЕКОНОМІЧНИХ РИЗИКІВ НА ПОКАЗНИКИ ДЕРЖАВНОГО БЮДЖЕТУ}

Анотація. Україна перебуває на шляху проведення реформи бюджетних відносин, одним із завдань якої є адаптація чинного законодавства до законодавства Європейського Союзу (СС) із метою створення європейських умов розвитку країни і бюджетної системи зокрема.

Бюджетний контроль - це вид державного фінансового контролю, комплексна i цілеспрямована система економіко-правових заходів уповноважених суб'єктів контролю, спрямована на забезпечення законності та ефективності дій учасників бюджетного процесу під час складання, розгляду, затвердження бюджетів, виконання, внесення змін та ухвалення звітів про виконання бюджетів, що становлять бюджетну систему України. 3 цих позицій назва глави 17 БКУ «Контроль за дотриманням бюджетного законодавства» визначає не сугність державного фінансового контролю, а його мету. Повноваження суб’єктів контролю, які встановлюються цією главою, мають переважно дублюючий характер, а чинний розділ 5 БКУ, хоч і встановлює види порушень бюджетного законодавства і заходи впливу за ці порушення, містить неточності та пробіли у формулюванні правових норм щодо проведення бюджетного контролю.

Нереалізованість на нормативному рівні принципів бюджетного контролю спричиняє вчинення бюджетних правопорушень. За звітами Рахункової палати під час проведення контрольних заходів щодо ефективності використання бюджетних коштів на забезпечення діяльності та виконання повноважень державними органами було виявлено понад 23 млн грн використаних із порушенням вимог чинного законодавства, і майже 313 млн грн неефективно. За розрахунками, державним бюджетом недотримано надходжень на суму майже 0,6 млн грн і перераховано до бюджетів із перевищенням установлених термінів 10,3 млн гривень. Отже, система бюджетного контролю потребує вдосконалення шляхом визначення сучасної концепції його організації i внесення відповідних змін у чинне законодавство. 3 цією метою було вивчено досвід закордонних країн, який свідчить про доцільність упровадження нової сучасної концепції бюджетного контролю, орієнтованої на попередній і поточний бюджетний контроль.

Ключові слова: бюджетне право, адаптація, бюджетний контроль, відповідальність, суб'єкти контролю, порушення, громадські кошти, фінансовий контроль.

Формул: 0; рис.: 0; табл.: 0; бібл.: 25.

Мищенко Л. В. к.юр.н., доцент кафедры правового обеспечения хозяйственной деятельности факультета № 6 Харьковского начионального университета внутренних дел; e-mail: forsazh088@gmail.com; ORCID ID: 0000-0003-4906-8287

Чича Р. П.

к.юр.н., доцент кафедры уголовного прочесса и организачии досудебного следствия факультета № 1 Харьковского начионального университета внутренних дел; e-mail: r_chicha@ukr.net; ORCID ID:0000-0003-3267-2840

Евдокименко С.В.

д-р юр.н., дочент кафедры финансов, учета и аудита

Харьковского экономико-правового университета; e-mail: evdokimenko_s_v@ukr.net; ORCID ID: 0000-0003-2924-6621 


\title{
АДАПТАЦИЯ БЮДЖЕТНОГО ЗАКОНОДАТЕЛЬСТВА УКРАИНЫ К ТРЕБОВАНИЯМ ЕВРОПЕЙСКОГО СОЮЗА И ВЛИЯНИЕ ЭКОНОМИЧЕСКИХ РИСКОВ НА ПОКАЗАТЕЛИ ГОСУДАРСТВЕННОГО БЮДЖЕТА
}

\begin{abstract}
Аннотация. Украина находится на пути проведения реформы бюджетных отношений, одной из задач которой является адаптация действующего законодательства к законодательству Европейского Союза (ЕС) с целью создания европейских условий развития страны и бюджетной системы в частности.

Бюджетный контроль - это вид государственного финансового контроля, комплексная и целенаправленная система экономико-правовых мероприятий уполномоченных контролирующих субъектов, направленная на обеспечение законности и эффективности действий участников бюджетного процесса во время составления, рассмотрения, утверждения бюджетов, исполнения, изменения и принятия отчетов о исполнении бюджетов, составляющих бюджетную систему Украины. С этих позиций название главы 17 БКУ «Контроль за соблюдением бюджетного законодательства» определяет не сущность государственного финансового контроля, а его цель. Полномочия контролирующих субъектов, которые устанавливаются данной главой, имеют преимущественно дублирующий характер, а действующая глава 5 БКУ, хотя и устанавливает виды нарушений бюджетного законодательства и меры воздействия за эти нарушения, содержит неточности и пробелы в формулировке правовых норм о проведении бюджетного контроля.
\end{abstract}

Нереализованность на нормативном уровне принципов бюджетного контроля влечет совершение бюджетных правонарушений. По отчетам Счетной палаты при проведении контрольных мероприятий по эффективности использования бюджетных средств на обеспечение деятельности и выполнение полномочий государственными органами было выявлено более 23 млн грн, использованных с нарушением требований действующего законодательства, и почти 313 млн грн - неэффективно. По расчетам, государственным бюджетом недополучено поступлений на сумму почти 0,6. млн грн и перечислено в бюджеты с превышением установленных сроков - 10,3 млн гривен. Итак, система бюджетного контроля требует усовершенствования путем определения современной концепции его организации и внесения соответствующих изменений в действующее законодательство. С этой целью изучен опыт зарубежных стран, который свидетельствует о целесообразности внедрения новой современной концепции бюджетного контроля, ориентированного на предыдущий и текущий бюджетный контроль.

Ключевые слова: бюджетное право, адаптация, бюджетный контроль, ответственность, контролирующие субъекты, нарушения, общественные средства, финансовый контроль.

Формул: 0; рис.: 0; табл.: 0; библ.: 25.

Introduction. Today is quite obvious that Ukraine is on the way of budgetary relations reform realization, one of which tasks is adaptation of the current legislation to the legislation of the European Union (hereinafter - EU) in order to create European conditions for the development of the country and budgetary system in particular.

Formation of the state budget is connected with the sphere of economic activity of the country. In the conditions of political and economic instability, the probability of unwanted changes in the state budget is growing significantly.

According to V.P. Hudkova, while studying economic risks, one should take into account the probability of achieving the expected result or its changes taking into account the influence of controlled and uncontrolled factors and the presence of direct and inverse relationships [1, p.14]. The increase in risks in the budget sphere contributes to the increase in the number of financial offenses. The establishment of negative tendencies in the implementation of the state budget from the detected economic risks requires the use of the system of budgetary control.

Problem's setting. Occasionally we should note that the significance of budgetary control has become more actual recently, when world crisis phenomena affected the processes of formation and execution of different level Ukrainian budgets, which requires searching of new ways of rational formation 
and usage of public financial resources accumulated in the country's budgetary system. Comparative and legal analysis of the financial legislation of Ukraine and the EU countries shows that in case of state financial control agencies presence the system of budgetary process control organization and its provision legal mechanism differ significantly.

The main part. According to the Budget Code of Ukraine (hereinafter - BCU), the budgetary process is the regulated by budgetary legislation process of drawing up, reviewing, approving, executing budgets, reporting on their implementation, as well as monitoring the observance of budgetary legislation. While determining the need for control in budgetary process, current legislation does not contain the notion of "budgetary control", does not establish in the system of budgetary system construction principles (Article 7 of BCU) the principle of control and legal responsibility [2].

Fully sharing the opinion that budgetary control is a kind of state financial control, integrated and telic system of economic and legal measures of authorized control subjects, aimed on providing of eligibility and effectiveness of budget process parties while drafting, reviewing, adoption of budgets, fulfillment, amending, considering reports on budgets' fulfillment, which compose the budget system of Ukraine [3, p. 39], seems to be necessary to introduce this definition into the law. From that point of view the title of Chapter 17 of Budget Code of Ukraine "Control on maintenance of budget legislation" means not the essence of state finance control but its aim. The powers of controlling subjects which are established by this chapter have mostly duplicative character while current Chapter 5 of BCU determines types of budget legislation violations and means of influence for such violations still contains inaccuracies and gaps in expression of legal norms concerning budget control.

According to the Law of Ukraine "On the Basic Principles of the Implementation of State Financial Control in Ukraine”, control measures are carried out to identify the actual state of affairs regarding the lawful and effective usage of state or municipal funds and properties, to identify the violations of legislation, to consider citizens' letters, complaints and appeals on legislation violations in a controlled institution [4]. The Strategy of Reforming the Public Financial Management System for 2017-2020 notes that the public financial management system in Ukraine is aimed on expenditure controlling, which makes responsible persons to focus on requirements compliance, rather than on the quality of public services [5]. So, budgetary control is carried out mostly as current or subsequent, documenting the violations and without affecting the quality of the budgetary process.

From our point of view, in order to timely establish the possible deterioration of the economic indicators of the state budget, within the budget control, a regular assessment of economic risks should be carried out in two main directions: a) formation of the revenue part of the state budget; b) use of state budget funds.

The determination of the impact of fiscal risks on the activities of business entities of the state sector of the economy on the indicators of the state budget is possible by regarding the Methodology for assessing the fiscal risks associated with the activities of business entities of the state sector of the economy, hereafter: the Methodology No. 7. According to Clause 3 of this Methodology: "Fiscal risks related to the activities of business entities are possible deviation of the forecast indicators of financial and economic activity of business entities from the planned level, which may lead to a decrease in budget revenues and / or require additional budget expenditures. Such risks are expressed in absolute figures or as a percentage of gross domestic product" [6].

In accordance with Clause 4 of the Methodology No. 7, fiscal risks include: 1) reduction of tax and non-tax revenues, in particular the part of the net profit (income) deducted to the state budget by state unitary enterprises and their associations, dividends (income) accrued on shares (shares, actions) of corporations the authorized capital of which includes the state property (in comparison with the planned volume); 2) the fulfillment by the state of guarantee obligations in case of impossibility of business entities to fulfill their obligations to creditors and the guarantor; 3 ) provision of additional state assistance to business entities to cover loss-making activities according to the Law of Ukraine "On State Aid to Business Entities"; 4) other risks that may lead to financial and other losses or problems with the entity's liquidity, which entail the expenditure of centralized funds of the state [6].

Factors that can lead to fiscal risks include: 1) adoption of regulatory acts related to the activities of business entities that may have an impact on the income and / or expenditure part of the state budget; 2) loss-making activity of business entities; 3) exchange rate losses of business entities that arise while performing obligations under foreign and economic agreements or while performing 
foreign currency borrowings; 4) decrease of demand and, accordingly, volumes of sales of goods, works and services, which are produced (provided) by business entities; 5) quasi-fiscal operations, which include operations that result in a net transfer of public funds through non-budget channels; 6) failure to receive receivables or losses in banks recognized by the National Bank as insolvent; 7) contingent liabilities assumed by business entities, which include the obligations that have been taken, but the terms and amounts of which depend on the occurrence of uncertain future events; 8) default charges, penalties; 9) losses resulting from gaps in the management and internal control system or through fraudulent actions; 10) negative effects of hostilities, terrorist acts or civil disturbances, as well as natural disasters and other circumstances of force majeure; 11) other factors [6].

According to Clause 6 of the Methodology No. 7, sources of information for the analysis of fiscal risks include: approved in accordance with the established procedure the dilution strategy and the investment plan of the entity in the medium-term perspective (three to five years); financial plan of business entities for the reporting period and a report on its implementation with explanatory notes to them; financial statements at the latest reporting date of the current year in the form defined by the National Accounting Standards 1 "General Requirements for Financial Statements", approved by the Ministry of Finance of Ukraine, in particular, the balance sheet (statement of financial position) (form No. 1) (with the deciphering of the articles balance sheet representing more than 10 percent of the currency of the balance sheet), statement of financial results (statement of comprehensive income) (form No. 2), cash flow statement (form No. 3), statement of equity (form No. 4); notes to the annual financial statements (form No. 5), approved by the Ministry of Finance of Ukraine; financial statements prepared in accordance with international financial reporting standards; information from the State Fiscal Service of Ukraine on payment of taxes, duties and other payments to the state budget, availability of the corresponding debt and excess of paid payments; information from the Ministry of Economic Development and Trade of Ukraine on performance of indicators of financial plans of business entities prepared in accordance with paragraph 13 of the Procedure for the preparation, approval and control of the implementation of the financial plan of the economic sector entity of the state sector of the economy approved by the Ministry of Economic Development and Trade of Ukraine and information on the efficiency of management of objects of state property, carried out in accordance with the Procedure for monitoring the implementation of functions concerning the management of state property objects and criteria for determining the effectiveness of management of state property objects, approved by the Resolution of the Cabinet of Ministers of Ukraine dated from June 19, 2007 No. 832 (Official Bulletin of Ukraine, 2007, No. 45, p.1839); other information received in accordance with the law [6].

The risk is determined according to the results of the analysis of the assessment, namely: 1st rank of risk - very high level of risk, which is established when an entity has a very high debt burden (the indicator "Leverage net debt" is greater than 5, and loss-making activity (net loss) or negative value of EBITDA, 2nd rank of risk - high level of risk, which is established when an entity has a high debt load (the indicator "Leverage net debt" is greater than 3) and coefficient by the exact liquidity (coverage) at the level, less (or equal) to 1 ; 3rd rank of risk - a significant level of risk, which is established when an entity has a high debt load (the indicator "Leverage net debt” is greater than 3 ) and current liquidity ratio (coverage) at the level from 1 to 2 (including 2); 4th risk rank - a moderate level of risk that is established when an entity has the meaning of the indicator "Leverage net debt" at the level of more (or equal) to 2; 5th rank of risk — low risk [6].

The Ministry of Finance of Ukraine on the basis of received information: conducts analysis and monitoring of indicators of activity of business entities; analyzes the size of risk identified by the management agencies related to the activities of business entities, their possible impact on the indicators of the state budget and measures to minimize such risks in order to take them into account when compiling and executing the state budget; provides to the management agencies and business entities, whose functions are administered by the Cabinet of Ministers of Ukraine, mandatory propositions and recommendations for the measures to be taken to minimize the impact of fiscal risks on the state budget, as well as receive from the said sub-information on the consideration of such propositions and recommendations and the state of their implementation; determines the annual amount of the reserve necessary to cover unforeseen expenditures that are not permanent and could not be foreseen, when drafting the state budget related to the materialization of fiscal risks; makes an annual report on fiscal risks related to the activities of business entities, which 
is published on the official web-site of the Ministry of Finance of Ukraine by May 31, the reporting year, and is used by the participants of the budget process at all stages of compilation and execution of the state budget for the relevant year [6].

The possible approach to the impact of economic risks on the indicators of the state budget is to determine the level of tax, inflation, deflation and currency risks.

While conducting the research of calculations with the budget, it is necessary to understand that the tax system of Ukraine is a collection of taxes, fees, other obligatory payments and contributions to the budget of Ukraine and state target funds that operate in accordance with the procedure established by the law. Ukrainian taxation system operates on the basis of the Tax Code of Ukraine. There are two systems of taxation: simplified and general. The entire tax system consists of national taxes and local taxes and fees [7, p. 139]. Tax (general economic) risks are considered from two positions (entrepreneur and state). The tax risk of the entrepreneur is related to the possible changes in the tax policy (reduction of tax privileges), as well as changes in the size of tax rates and terms of charging (paying) taxes. Instability of tax legislation increases the level of tax risk. The tax risks of the state are the possible reduction of budget revenues as a result of ill-considered changes in tax policy and / or the size of tax rates. At the same time, the reduction of tax revenues may be caused both by a decrease in the level of tax rates and their growth (Curve Lafer), [1, p. 39-40]. Tax risks also take into account the timeliness and completeness of proceeds to the execution.

Inflation risk is the risk that, with the growth of inflation, the cash flows of business entities, depreciating in terms of purchasing power rather than increasing. Under such conditions, the entrepreneur and the state have real losses. Inflation is a depreciation of money and, accordingly, an increase in prices. Deflation risk is the risk of a fall in price levels, a deterioration of business conditions and a decline in profits, when deflation is rising. Deflation - is a process that turns into inflation, it manifests itself in lowering prices, and, accordingly, in increasing the real purchasing power of money [8, p. 33].

The problem of currency risk in economic theory and practice first appeared in the late 70's of the XX century, after the signing of the Jamaican Agreement (Kingston, Jamaica, 1976) by the Member-States of the International Monetary Fund. One of the main principles of this agreement was the introduction of a free-exchange rate regime based on floating exchange rates - flotation. The greatest acuteness of this problem has gained in the 80's and 90's of the XX century and remains relevant for the future. First of all, this is due to the sharp increase in volumes of international trade and financial transactions, unpredictable fluctuations in exchange rates, and the growth of volumes of currency speculation, which causes a sharp increase in the dependence of the financial results of enterprises and financial and credit institutions on currency risk. From purely economic point of view, such a risk is the result of imbalances in assets and liabilities for each currency in terms and amounts [9, p. 67-72].

The level of violations of budget legislation is the evidence of unsatisfactory state of the execution of the state budget. According to the results of check-outs says that budget delinquencies are repeated year on year, acquiring the systematic character. On Accounting Chamber reports while fulfilling the controlling measures concerning the effectiveness of budget funds usage for ensuring activities and performing powers of public authorities more than 23 million UAH have been identified as used with violation of the requirements of the current legislation, and almost 313 million UAH were used inefficiently. According to the calculations, the state budget short received income of almost 0.6 million UAH and also 10.3 million UAH were transferred to budgets exceeding the established deadlines [10, p. 80]. While auditing the effectiveness of the budget funds usage by the state financial control bodies, the auditors of the Accounting Chamber adjudged the excess of State Treasury, State Fiscal Service (SFS) employees number and improper work organization on planning the expenses for their maintenance, as well as the need to improve the internal control in these bodies system [5, p. 92105]. On the results of the inspection was recognized the need to improve the legal and regulatory framework governing the control organization, since violations of budget legislation are reproduced annually, systematically and indicate the imperfection of control measures. The Accounting Chamber annual reports analysis leads to the conclusion about the typical nature of budget legislation violations, namely: 1) usage of state budget funds with budget legislation violation; 2) the State Budget of Ukraine losses as a result of illegal management decisions; 3 ) ineffective usage of budget funds provided for the implementation of government programs, as well as illegal allocation of funds from the reserve fund of the state budget; 4) absence of internal control system at public sector of economy enterprises; 5) 
planning of state budget expenditures with violation of the current legislation and in absence of legal grounds; 6) diversion of state budget funds into accounts receivable; 7) implementation of expenditures for budgetary institutions financing from different budgets simultaneously; 8) budgetary violations related to the usage of inter-budgetary transfers and so on.

An important part of the research on general issues of committing offenses is the definition of the real state of accounting. Such verification involves determining the reliability of reporting and accounting, its completeness and compliance with applicable law. To this end, it is advisable to check the completeness and accuracy of the display of data on the main types of business transactions. Examination of acts of inspection of the State Fiscal Service of Ukraine provides information on compliance with the company's tax legislation [7, p. 150].

Budgetary legislation of many countries uses the notion "violation of budgetary legislation" instead of "budgetary delinquency". For example, according to Art. 281 of Budget Code of Russian Federation budgetary legislation violation is non-fulfillment or improper fulfillment of established by Budget Code order of drawing up and adoption of budget drafts, adoption of budgets, budget executions and control on budget execution of Russian Federation budgetary system [11]. More substantial notion of budgetary legislation violation is given in Budget Code of Republic of Belarus: "non-fulfillment or improper fulfillment of requirements imposed by this Code and other budgetary legislation acts on drawing up, reading, adoption, execution of budgets, receiving and usage of public funds are vindicated as budgetary legislation violations and entail the of coercive measures to offender for budget legislation violation under this Code and other legislative acts" [12].

Nevertheless there is a question which notion is better to use "violation of budgetary legislation" or "budgetary delinquency"? Different points of view on this notions correlation exist among financial law specialists. One of them insists on notions identity [13, p. 233], others stay on position of its correlation as general and particular adducing next arguments: any budgetary delinquency violates budgetary legislation but not every budgetary legislation violation is budgetary delinquency [14, p. 114].

From our point of view this notions are not identical. The first is broader in scope, since it includes budget offenses and specifically crimes, administrative and budgetary minor offences and also wide range of violations that do not have the signs and composition of the offense.

National legislation uses the concept of a "budget law violation" which, in accordance with Art. 116 of the Budget Code of Ukraine is defined as a violation of the norms established by this Code or other budgetary legislation by the participant of the budgetary process regarding the drawing up, reviewing, approval, modification, budget execution and reporting on its execution. The analysis of this article shows that they concern: first of all, budgetary procedures (for example, violation of deadlines for budget requests submission or their failure to submit, identification of public funds unreliable amounts while planning budget targets, time limits and reporting requirements violation, etc.), the second, the budgetary funds usage order (for example, misuse of public funds, or provision of loans from the budget in violation of the law requirements), and thirdly, violation of the budgetary funds accounting requirements. Thus, the legislator provides budget offenses types, since they are united by the object of the offense - budgetary funds, subjects - participants in the budgetary process and legal responsibility in the form of financial measures of influence. Enforcement measures for committed budget offenses are established in the Art. $117 \mathrm{BCU}$ and except for such an event as a warning on improper performance of budgetary legislation have material content, in other words, financial and legal responsibility is applied, which is another argument in favor of determining a budget delinquency.

At the same time, even direct non-fulfillment of budget assignments can't be regarded as a budget delinquency, since it is not stipulated in Art. 116 of the BCU. This inconsistence is to some extent settled by the Criminal Code of Ukraine (hereinafter - CCU) and the Code of Ukraine on Administrative Offenses (hereinafter - CUAO), which establish responsibility not for a budget offense, but for violation of budget system legislation, which is interpreted more broadly than in the Budget Code. Despite the different names in the Criminal Code, Code of Ukraine on Administrative Offenses and the Budget Code, Yu. A. Prudov argues that the notions of "budget delinquency" and "violation of the budget system legislation" (CCU and CUAO) are essentially identical notions [15, p. 32-33]. Not sharing this view, it should be noted that for budgetary legislation violation are provided various types of legal liability, depending on the corpus delicti of the offense or a crime, and it does not abolish the financial responsibility for purely fiscal offenses. 
In the scholars' opinion the notion "budget delinquency" alternatively to "budgetary legislation violation" is characterized by object features - public funds and subjects, participants of budgetary process [16]. Ya. R. Dehtiar determines budget delinquency as guilty, unlawful (violation of budget legislation) act of person, connected with the order of drawing up and examination of budget drafts, adoption, fulfillment and control on budget fulfillment, for which the CCU establishes budgetary responsibility imposed by the state financial authorities [17, p. 21]. Sharing this opinion, we believe that the procedure for its application and punishment belongs to the peculiarities of a budget delinquency which has financial nature and lays in the disposes of budget control authorized subjects.

The EU countries experience of budgetary control organization shows that it's aimed on execution of control measures at the stage of preliminary consideration of the requirements for budget programs state financing. The state finance control system in France is made in such way that the General Directorate of State Accounting under the Ministry of Finance is charged with servicing the movement of budgetary funds, like the Treasury in Ukraine, and also, in fact, fulfilling the functions of the preliminary financial control over the compliance of approved budgets and other financial standards by budget managers.

One more agency in budgetary control subjects system in France is the Budget Office. The main method of financial controller work is approval of billing or other financial documents. The visa of the financial controller is put down before the budgetary funds manager places his signature and its absence blocks their right to dispose funds. Unblocking costs is possible only with a written order of Minister of the Economy, Minister of the Finance. The provision of advisory service to fund managers is also the function of financial controllers.

Another agency of state financial control is the General Inspectorate of Finance, a body that contributes to the legal and effective management of public finances with the help of its control activities. The General Inspectorate controls public financing of the public legal sector in the whole by conducting audits, inspections, studies and other control measures. In the end of any inspection, the head of the mission draws up a report, which resembles the form for withdrawal to objections to the audit or verification act in structure, used in Ukraine: in the first part, inspectors note deviations from the norm; the second part of the report, if necessary, fills the management of the controlled entity; the third part, if there are objections to the inspectors' conclusions, are filled again by the inspectors. The second form of control that inspectors use is audit. While it's held, the activities of one controlled entity is being analyzed, the implementation of one budget program or even the implementation of a separate procedure for using budget funds could be analyzed. By nature, this audit can be called financial and administrative (in the understanding of Ukrainian lawyers - mixed), because under its results is made an assessment both on the reliability of financial reporting and the effectiveness of budgetary funds usage. The third form of control, which in France is called the research mission, is used by the General Inspectorate of Finance, mainly on appeals to its ministerial leadership. This form of control, in fact, pursues the same goals as performance audit in Ukraine: assessment of the budget program implementation, the establishment of its weaknesses and making sound proposals to improve the quality of services. The fourth form of control (giving the advisory service) is that upon the appeals of the directorates of the Ministry of Finance, the General Finance Inspectorate sends inspectors for 2 to 6 months period to provide the assistance to directorate [18].

In the budgetary funds control system while dividing control functions the presence of controlling subjects' activity harmonization is necessary. Scientific literature proposes to create Interdepartmental Council under the Ministry of Finance which will coordinate the activity of state financial control special bodies [18]. As a whole, the experience of French budgetary control organization indicates the strict division of responsibilities between specially created state financial control bodies which have powers to control the budgetary funds and powers provided by the law that are methodologically defined for each authority.

Likewise to French budgetary governing board, Great Britain has Office for Budget Responsibility (hereinafter OBR) - board which prognoses the development of budgetary financing, makes propositions to government concerning budgetary planning, taxes policy, creates conditions for stable financing and state sector development and permanently controls state 
expenditures to make additional financing for social security services. OBR has also the power to block non-effective expenditures [19, p. 31-34].

It should be noted that participants of budget relations bear civil, disciplinary, administrative or criminal liability for budget legislation violation in accordance to law, as it's stipulated in Art. 121 of the BCU. However, in this legal definition, the principle of legal responsibility concretization for budget legislation violation is not taken into account, as it gives the impression of applying several types of responsibility for one punishment. Consideration of other impact measures which are established in Art. 117 of the BCU also leads to the conclusion that the principle of legal responsibility individualization is not taken into account, inasmuch as for the implementation of expenditures with violation of budget requirements, which can be done only by the budgetary funds administrator, an unobjectionable expunging of budget the penalty is prescribed.

Nowadays Ukraine has the situation, when the implementation of control by the controlling entities over the observance of the budget legislation is not legally justified, as there is no defined control procedure and powers of controlling entities for the application of financial measures of influence. In case of detecting budget violations, controlling entities have the right to apply such measures as suspending budget allocations and stopping operations with budget funds, as well as imposing administrative fines on a guilty person of budget violations. However, the first two measures have negative consequences for employees of budget institutions, all recipients of budget funds, that is, consumers of public goods. But, the latter may not be guilty of violations such as submission of false reports and information on the implementation of local budgets, or failure to comply with accounting requirements, or late or incomplete submission of reports on budget execution, etc., for which the specified punishment is imposed. The application of administrative penalties for guilty officials for these budget violations, the procedure and amount of these penalties is not set by the norms of the Budget Code of Ukraine [20, p. 207].

Budget legislation violation as a rule is accompanied by financial legislation violations responsibility for which is written in Art. $164^{2}$ of the CUAO - "Financial legislation violations". Budgetary system of Ukraine violation cases (Art. 164 ${ }^{12}$ ) are heard and decisions are taken by judges of district (city) courts (p.1, Art. 221 of the CUAO).

Criminal liability in budgetary relationship sphere is prescribed by Art. 210 of the CCU for next offences: inappropriate use of public funds, making budget expenses or extension of credit from budget without establishing budgetary obligations or with its exceeding. It's also prescribed in Art. 221 of the CCU: promulgation of regulations which decrease of budget revenues or increase budget extensions in disregard of law. The perpetrator of the crime in both cases is an official. At the same time, the target of this crime should be budgetary funds on a large scale (the amount is a thousand or more exceeding the non-taxable minimum of citizens 'incomes) or on especially large amount (the amount is three thousand times or more exceeding the non-taxable minimum of citizens' incomes). The common in bringing to administrative or criminal responsibility for budget legislation violation is that is known that the subject of the violation or the offense is an official, and also is known the punishment entry. In contrast to financial and legal responsibility, types of legal liability are specified in court.

Recently, an increased interest in the problem of responsibility of subjects of budgetary legal relations appears in the financial law science. Transformation of the system of financial and legal regulation, intensive development and accumulation of financial legislation in Ukraine contributed to the allocation of this type of legal responsibility as a financial and legal [21, p. 111]. Today, in the legal science, the issue of formalization of the budgetary responsibility in legislation is also being raised. The current legislation does not directly point to the existence of such a liability, as the BCU does not show directly the possibility of applying budgetary liability measures to budget legislation violators, but after analysis of its norms can make a conclusion about its induction [20]. Thus, implementation of budgetary responsibility measures as a kind of financial and legal responsibility for commitment budget offenses is quite appropriate.

The main financial plan of the country is the state budget of Ukraine for one year. Offenses committed in this sphere are the most harmful and have a specific nature and so agreeably the financial and legal responsibility for its commission has certain features.

E. Yu. Hrachova believes that among coercive measures applied for budget legislation violation can be identified, measures; protection measures and measures of responsibility. Preventive measures are applied with the aim of stopping unlawful actions and removing their harmful consequences. They include: the 
blocking of expenses, the suspension of operations on accounts with credit institutions. Protection measures, in her opinion, are aimed at compensating for harm caused by a wrongful act (for example, payment of compensation, withdrawal of budget funds, etc.). Responsibility measures are embodied in the creation for the offender of an additional obligation to suffer adverse consequences (for example, prevention, removal of budgetary funds, etc.) [22, p. 61-62].

I. A. Sikorska does not agree with this viewpoint, on the author's idea the scientists contradict themselves, because the measures of protection formulated by them, are applied already with the fact of damage, and therefore, there was a law violation, and accordingly, it is necessary to speak about the measures of responsibility, used for their realization. The same applies to the preventive measures. In her opinion, this is the peculiarity of financial and legal responsibility for the budget legislation violation, which is a coercion method imposed to prevent the new offenses committing [23, p. 110].

V. D. Chernadchuk determined the signs of fiscal responsibility as follows: firstly, a limited range of subjects, represented by the obliged subject (subject of budget offense) and the authorized subject (subject, empowered by the budgetary legislation and the right to carry out proceedings concerning the budget violation offences and to make decisions concerning the penalties (measures)) imposition. The range of subjects of budget offense is limited only by the part of participants of budget process, namely: administrators and recipients of budget funds and the local councils in the field of budget planning. The authorized subjects are the persons, representing the subject realizing the control and investigation of the budget offense fact and subjects who take the decision concerning the penalty imposition for the budget offense. The first are the officials, and the other are the heads of the local councils. Secondly, the rights and obligations of subjects in legal relationships of the proceedings are determined exclusively by the budget legislation acts. Thirdly, the limited application period: penalty (measure) can be imposed only during the relevant budget period and can not be applied in the next budget period [24, p. 46].

Taking into account the above-mentioned provisions, it is possible to determine a number of fiscal responsibility features as the final result of budget control: 1) fiscal legislation as the legal basis for prosecution, based on the relevant principles which is necessary to introduce in Art. 7 of BCU; 2) the basis of liability is a committed budget offense; 3 ) for the offender it has some negative consequences of property and personal non-property character, due to the fiscal sanctions specific character; 4) the subjects of this type of responsibility are the participants of budget process; 5) it is implemented in a specific procedural form, differing from the other types of liability; 6) purpose of the budgetary responsibility is punitive and preventive; 7) system of the controlling entities is authorized to implement measures aimed to influence the violators of budgetary legislation.

Conclusions. Procedure of the financial measures applications for the budget violations is not regulated by the $\mathrm{BCU}$ and other normative-legal acts. The prosecution right for the budget violations on the basis of the inspection certificate previewed by the Art. 26 of the Budget Code of Ukraine as the control method is not established. In practice, the prosecution procedure for budget violations is carried out on the basis of report about the budget offenses or the audit certificate and documents attached thereto. The content of all these documents is not defined. In the document, consisted of the audit or the inspection results it is important to determine the type of budget offense, the amount of budget funds covered by the budget offense, and measures to impose it, that is, to take into account the consequences of budget offense commission [25, p. 37].

The punitive function of budget-legal responsibility is the direction of legal action on the violator. The enforcement actions applied for the budget violations consist in negative consequences occurrence of the property or personal character for violator.

The restorative function is aimed at the damage elimination which has been caused to the public interest. Broadly defined, the object of the restorative influence are the relations existing in the process of public budget activity. As the offenses in the specified sphere can cause damage not only to the property relations, but also to destabilize the organizational and administrative relations, and therefore to disturb the economic interests of the state in general, by the budget system destabilizing, it is necessary to give a great importance to the restorative function of budgetary responsibility.

The educational function of budget responsibility consists in the high level forming of legal awareness, admissible and desirable stereotypes of behavior, respect of law. It should consolidate the valuebased ideals and to have the reverse effect on the legal consciousness of the subjects of legal relations. Thus, the educational function is manifested through the legal culture formation among the subjects of budgetary relations. 
Scientific literature suggests that the budget responsibility can be divided into three separate stages, namely: formation (budget offense committing), specification (determining of specific measure and the amount of budget-legal responsibility), and implementation (the use of specific influencing mean on the offender or punishment). The specificity of the financial and legal responsibility in the field of budgetary legal relations is that the special influence measures application is realized within it limits, which have a negative significance for the budget process. In these legal relations, the right of state represented by the relevant authorities concerning the application of influence measures corresponds to the offender obligation to undergo the temporary restrictions of the financial or normative nature, previewed by the measures of influence on the budget violations, to result their activities in accordance with the budget-legal provisions, not allowing the further violations of budget legislation. We support the opinion of scholars that such a legal relationship forms the content of financial and legal responsibility in the field of budget legal relations, and, materializing through the actions of subjects, it acquires its real existence, causing the status of responsibility [24, p. 47-49].

Then, making a general conclusion, we should note that in order to improve the fiscal control relationship, taking into account theoretical and legal basis of fiscal control, the current state of functioning of budget relations and international experience, it is necessary to amend the current legislation (BCU) in order to introduce the concepts: "budget control", "budget misdemeanor", "budget liability", and the latest methods of control, such as financial and administrative audit, audit of efficiency, decision of controlling entity, blocking of expenses, monitoring, advisory consultative assistance, an assessment of the quality of public services that will provide legal grounds for the new organization of the budget control system.

In this case, the timely identification of possible deterioration of the economic indicators of the state budget within the framework of fiscal control is of personal value. Timely identification of risk gives an opportunity to estimate the cost impact of economic risks on the indicators of the state budget and to prevent undesirable consequences. The possible approach to the impact of economic risks on the indicators of the state budget is to determine the level of tax, inflation, deflation and currency risks. Fiscal risks and a wide range of market, financial and other factors of their occurrence determine, from our point of view, the direction of action within the fiscal control to identify possible changes in the state budget. At the same time, in order to determine the size of the impact of fiscal risks on the indicators of the state budget, the availability of the necessary data for the analysis of the relevant indicators is provided.

Thus, carrying out economic analysis and estimating fiscal (economic) risks within the framework of fiscal control will promote the development of economic activity of state enterprises and budgetary institutions and will strengthen control measures on effective formation and use of revenue and expenditure parts of the state budget of Ukraine.

1. Управління економічними ризиками : навчально-методичний посібник для студентів освітнього ступеня «магістр» галузі знань 05 «Соціальні та поведінкові науки» спеціальності 051 «Економіка» денної та заочної форм навчання / В. П. Гудкова, О. В. Пилипенко, В. І. Творонович. - Київ : Вид-во ДЕТУТ, 2016. — 275 с.

2. Бюджетний кодекс України : Закон України від 08.07.2010 № 2456-VI // Відомості Верховної Ради України. 2010. — № 50-51.

3. Гетманець О. П. Бюджетний контроль: організаційно-правові засади : монографія / О. П. Гетманець. - Харків : Екограф, 2008. - 308 c.

4. Про основні засади здійснення державного фінансового контролю в Україні адміністрації : Закон України : від 16.10.2012 № 5463-VI // Відомості Верховної Ради України. - 1993. — № 13.

5. Стратегії реформування системи управління державними фінансами на 2017-2020 : Розпорядження Кабінету Міністрів України від 08.02.2017 № 142-p [Електронний ресурс]. - Режим доступу : https://www.kmu.gov.ua/ua/npas/249797370.

6. Методика оцінювання фіскальних ризиків, пов'язаних з діяльністю суб'єктів господарювання державного сектору економіки : затверджено постановою Кабінету Міністрів України від 11 січня 2018 р. № 7.

7. Свдокіменко С. В. Теорія і практика судово-економічної експертизи : монографія / С. В. Свдокіменко. Харків : Панов, 2016. - 540 с.

8. Відоменко О. І. Економічні ризики та методи їх вимірювання : навчально-методичний комплекс для студентів усіх форм навчання спеціальності 7.050107 «Економіка підприємства»/ укладач к.е.н., доцент О. I. Відоменко. - Київ : КIMЕП, 2003. - 97 c.

9. Писаревський I. М. Управління ризиками : навч. посібник / I. М. Писаревський, О. Д. Стешенко. - Харків : ХНАМГ, 2008. - 124 c.

10. Звіт Рахункової палати за 2015 рік [Електронний ресурс]. — Режим доступу : www.ac-rada.gov.ua.

11. Бюджетный кодекс Российской Федерации : Закон РФ от 31.07.1998 № 145-Ф3 [Электронный ресурс]. Режим доступа : http://www.consultant.ru/popular/budget. 
12. Бюджетный кодекс Республики Беларусь : Закон РБ от 17 июня 2008 г. [Электронный ресурс]. - Режим доступа : http://pravo.levonevsky.org/kodeksby/bydgkodecs/201002/index.htm.

13. Батыров С. Е. Проблемы применения и перспективы развития ответственности за нарушение бюджетного законодательства / С. Е. Батыров // Финансовое право. - 2003. - № 2. - С. 231-240.

14. Бюджетное право : учебник / под ред. Н. А. Саттаровой. — Москва : Деловой двор, 2009. — 269 с.

15. Прудов Ю. О. Фінансово-правові засади соціальних гарантій військовослужбовців в Україні : дис. ... канд. юрид. наук : 12.00 .07 / Ю. О. Прудов. - Київ, 2007. — 210 с.

16. Бюджетний кодекс України : наук.-практ. коментар : станом на 1 берез. 2011 р. / за ред. Л. К. Воронової, М. П. Кучерявенка. - Харків : Право, 2011. - 606 с.

17. Дегтяр Я. Р. Бюджетні правопорушення, як підстави відповідальності за чинним законодавством України / Я. Р. Дегтяр // Економіка та право. — 2016. — № 1 (43). — С. 19-24.

18. Стефанюк I. Б. Зарубіжний досвід! Є чому навчатися, $є$ що запозичувати (Організація урядового фінансового контролю у Франції) [Електронний ресурс] / І. Б. Стефанюк ; Державна аудиторська служба України. — 2004. - Режим доступу : : http://www.dkrs.gov.ua/kru/uk/publish/printable_article/34227;jsessionid=9350093E036CC F533DA5DC9A200583E1.app1.

19. Spring Budget 2017 : News from Parliament [Electronic resource] / UK Parliament News. — — 2017. — March 14. — Availiable at : www.parliament.uk.

20. Гетманець О. П. До питання відповідальності за порушення бюджетного законодавства / О. П. Гетманець // Форум права. - 2011. - № 1. - С. 206-210.

21. Фінансове право України : навч. посібник для студ. вищ. навч. закладів / Л. К. Воронова, М. П. Кучерявенко, Н. Ю. Пришва та ін. ; за ред. Л. К. Воронової, М. П. Кучерявенка. — Київ : Правова єдність, 2009. — 485 с.

22. Финансовое право : учебник / под ред. Е. Ю. Грачевой. - Москва : Право и закон, КолоС, 2003. - 384 с.

23. Сікорська I. А. Правова відповідальність за порушення бюджетного законодавства : дис. ... канд. юрид. наук : 12.00.07 / I. А. Сікорська. - Ірпінь, 2004. - 210 с.

24. Чернадчук В. Д. Бюджетні правовідносини як об’єкт правової охорони / В. Д. Чернадчук // Держава та регіони. - 2011. — № 2. - С. 45-50. - (Серія : Право).

25. Гетманець О. П. Фінансові санкції як заходи впливу за порушення бюджетного законодавства / О. П. Гетманець // Право та державне управління. — 2011. — № 1. - С. 36-39.

Стаття рекомендована до друку 03.12. 2018

(C) Міщуенко Л. В., Чича Р. П., Свдокіменко С. В.

\section{References}

1. Hudkova, V. P., Pylypenko, O. V., \& Tvoronovych, V. I. (2016). Upravlinnia ekonomichnymy ryzykamy [Economic risk management]. Kyiv: Vydavnytstvo DETUT [in Ukrainian].

2. Verkhovna rada Ukrainy. (2010). Biudzhetnyi Kodeks Ukrainy, zakon Ukrainy vid 08.07.2010 № 2456-VI [The Budget Code of Ukraine, the Law of Ukraine dated from 8 July 2010 No. 2456-VI]. Vidomosti Verkhovnoi rady Ukrainy - Bulletin of Verkhovna Rada of Ukraine, 50-51 [in Ukrainian].

3. Hetmanets, O. P. (2008). Biudzhetnyi control: orhanizatsiini ta pravovi aspekty [Budgetary control: organizational and legal aspects]. Kharkiv: Ekograph [in Ukrainian].

4. Verkhovna rada Ukrainy. (1993). Pro osnovni zasady zdiisnennia derzhavnyoho finansovoho kontroliu v Ukraini: Zakon Ukrainy vid 16.10.2012, № 5463-VI [On the Main Principles of the Administration of the State Financial Control: the Law of Ukraine dated from 16 October 2012 № 5463-VI]. Vidomosti Verkhovnoi rady Ukrainy - Bulletin of Verkhovna Rada of Ukraine, 13 [in Ukrainian].

5. Kabinet Ministriv Ukrainy. (2017). Stratehii reformuvannia systemy upravlinnia derzhavnymy finansamy na 20172020: Postanova Kabinetu Ministriv Ukrainy vid 08.02.2017 № 142-p [The strategies of reforming of the public finance management system for 2017-2020: Decree of the Cabinet of Ministers of Ukraine dated from 8 February 2017 № 142-p]. Retrieved from https://www.kmu.gov.ua/ua/npas/249797370 [in Ukrainian].

6. Kabinet Ministriv Ukrainy. (2018). Metodyka otsiniuvannia fiskalnykh ryzykiv, poviazanykh z diialnistiu subiektiv hospodoriuvannia derzhavnoho sektoru ekonomiky: Postanova Kabinetu Ministriv Ukrainy vid 11.01.2018 № 7) [Methodology for estimating fiscal risks related to the activity of economic entities of the state sector of the economy: Resolution of the Cabinet of Ministers of Ukraine dated from January 11, 2018, № 7]. Retrieved from http://zakon.rada.gov.ua/laws/show/7-2018-\%D0\%BF.

7. Yevdokimenko, S. V. (2016). Teoriia i praktika sudovo-ekonomichnoi ekspertyzy [Theory and practice of forensic and economic expertise]. Kharkiv: Panov [in Ukrainian].

8. Vidomenko, O. I. (2003). Ekonomichni ryzyky ta metody ikh vymiriuvannia [Economic risks and methods of their measurement]. Kyiv: KIMEP [in Ukrainian]. Ukrainian].

9. Pisarevskyi, I. M., \& Steshenko, O. D. (2008). Upravlinnia ryzykamy [Risk Management]. Kharkiv: KSAME [in

10. Rahunkova Palata Ukrainy. (2016, April 29). Zvit Rahunkovoi Palaty Ukrainy za 2015 rik [The 2015 year Report of the Accounting Chamber of Ukraine]. Retrieved from www.ac-rada.gov.ua [in Ukrainian].

11. Biudzhetnyi Kodeks Rossiiskoi Federatsii: Zakon Rossiiskoi Federatsii ot 31.07.1998 [The Budget Code of Russian Federation: the Law of Russian Federation dated from 31 July, 1998]. Retrieve from http://www.consultant.ru/popular/budget [in Russian].

12. Biudzhetnyi Kodeks Respubliky Belarus: Zakon respubliky Belarus ot 17.06.2008 [The Budget Code of Belarus Republic: the Law of Belarus Republic dated from 17 June 2008]. Retrieved from http://pravo.levonevsky.org/kodeksby/bydgkodecs/201002/index.htm [in Russian].

13. Batyrov, S. Ye. (2003). Problemy primeneniya i perspektivy razvitiya otvetstvennosti za narushenie byudzhetnogo zakonodatel'stva [The problems of usage and the perspectives of the development of the budget legislation violation]. Finansovoe pravo - Financial Law, 2 [in Russian].

14. Sattarova, H. A. (Ed.). (2009). Biudzhetnoe pravo [Budget Law]. Moscow: Delovoi dvor, 2009 [in Russian].

15. Prudov, Yu. O. (2007). Finansovo-pravovi zasady sotsialnykh harantii viiskovosluzhbovtsiv v Ukraini [Financial and legal basis of social warranties of the service members in Ukraine]. Candidate's thesis. Kyiv [in Ukrainian].

16. Biudzhetnyi Kodeks Ukrainy: naukovo-praktychnyi komentar vid 01.03.2011 [The Budget Code of Ukraine: scientific practical commentary by 1 March, 2011]. (2011). L. Voronova, M. Kucheriavienko (Ed.). Kharkiv: Pravo [in Ukrainian]. 
17. Dehtiar, Ya. R. (2016). Biudzhetni pravoporushennia iak osnovy pravovoi vidpovidalnosti za zakonodavstvom Ukrainy [Budget delinquencies as the foundations of legal accountability by the legislation of Ukraine]. Ekonomika i pravo - Economy and Law, 1 [in Ukrainian].

18. Stefaniuk, I. B. Derzhavna audytorska sluzhba Ukrainy. (2004). Zakordonnyi dosvid! Ye chomo navchytysia, ye shcho adoptuvaty (Orhanizatsiia uriadovoho finansovoho kontroliu u Frantsii) [International experience! There is smth to study, there is smth to be adopted (The organization of governmental financial control in France)]. Retrieved from http://www.dkrs.gov.ua/kru/uk/publish/printable_article/34227;jsessionid=9350093E036CC F533DA5DC9A200583E1.app1 [in Ukrainian].

19. UK Parliament News. (2017, March 14). Spring Budget 2017: News from Parliament. Retrieved from www.parliament.uk.

20. Hetmanets, O. P. (2011). Do pytannia pro vidpovidalnist za porushennia biudzhetnoho zakonodavstva [To the question of the responsibility for budget legislation violations]. Forum prava - The forum is right, 1 [in Ukrainian].

21. Voronova, L. K., Kucheriavenko, M. P., \& Pryshva, N. Yu. (Ed.) (2009). Finansove pravo Ukrainy [The Financial Law of Ukraine]. Kyiv: Pravova yednist [in Ukrainian].

22. Hracheva, Ye. Yu. (Ed.) (2003). Finansovoe pravo Ukrainy [The Financial Law of Ukraine]. Moscow: Pravo i zakon, KoloS [in Ukrainian].

23. Sikorska, I. A. (2004). Pravova vidpovidalnist za porushennia biudzhetnoho zakonodavstva [Legal responsibility for budget legislation violations]. Candidate's thesis. Irpin [in Ukrainian].

24. Chernadchuk, V. D. (2011). Biudzhetni pravovidnosyny yak obiekt pravovoi okhorony [Budgetary legal relationship as an object of legal protection]. Derzhava ta rehiony. Seriia: Pravo - State and regions. Series: law, 2 [in Ukrainian].

25. Hetmanets, O. P. (2011). Finansovi sanktsii yak zakhody vplyvu za porushennia biudzhetnoho zakonodavstva [Financial sanctions as a measure of influence for the budget legislation violations]. Pravo ta derzhavne upravlinnia — Law and state management, 1 [in Ukrainian].

The article is recommended for printing 03.12.2018

(C) Mishchenko L. V., Chycha R. P., Yevdokimenko S. V., 